\title{
DIVERSITY AND DISTRIBUTION OF THE SPIDERS (ARACHNIDA: ARANEAE) FROM KAILASHAHAR: FIRST RECORD OF NINE SPECIES FROM TRIPURA, INDIA
}

Sandipan Das ${ }^{1}$, Dhrubjyoti Sharmaㄹ, Debobrata Deb ${ }^{3}$, Anwesha Dey ${ }^{4}$, Atish Chandra Ghosh ${ }^{5}$, Mitrajit Deb ${ }^{6}$, Abhijit Datta ${ }^{4}$, Soumitra Nath², Bibhas Deb², H. Reshmi Singha ${ }^{4}$, Rajat Debnath ${ }^{4}$, Sunil Nautiyal7 ${ }^{7}$ Petr Slama ${ }^{8}$, Shubhadeep Roychoudhury ${ }^{1}$

\footnotetext{
${ }^{1}$ Department of Life Science and Bioinformatics, Assam University, Silchar 788011, India

${ }^{2}$ Bioinformatics Centre and Biotech Hub, Gurucharan College, Silchar 788004, India

${ }^{3}$ Ramkrishna Mahavidyalaya, Kailashahar, Tripura 799277, India

${ }^{4}$ Ambedkar College, Fatikroy, Unakoti, Tripura 799290, India

${ }^{5}$ Government Degree College, Dharmanagar, Tripura 799250, India

${ }^{6}$ Department of Zoology, Royal Global University, Guwahati 781035, India

${ }^{7}$ Centre for Ecological Economics and Natural Resources, Institute for Social and Economic Change, Bengaluru 560072, India

${ }^{8}$ Department of Animal Morphology, Physiology and Genetics, Faculty of AgriSciences, Mendel University in Brno, Zemědělská 1, 61300 Brno, Czech Republic
}

Link to this article: https://doi.org/10.11118/actaun.2021.054

Received: 25. 7. 2021, Accepted: 8. 11. 2021

To cite this article: DAS SANDIPAN, SHARMA DHRUBJYOTI, DEB DEBOBRATA, DEY ANWESHA, GHOSH ATISH CHANDRA, DEB MITRAJIT, DATTA ABHIJIT, NATH SOUMITRA, DEB BIBHAS, SINGHA H. RESHMI, DEBNATH RAJAT, NAUTIYAL SUNIL, SLAMA PETR, ROYCHOUDHURY SHUBHADEEP. 2021. Diversity and Distribution of the Spiders (Arachnida: Araneae) from Kailashahar: First Record of Nine Species from Tripura, India. Acta Universitatis Agriculturae et Silviculturae Mendelianae Brunensis, 69(6): 617-628.

\begin{abstract}
Spiders are one of the most diverse and numerically abundant arthropods. They have a wide distribution and inhabit different types of habitats. Their occurrence and distribution function as a bio-indicator of that area and their presence is influenced greatly by the corresponding habitat and vegetation types. In this study the spider fauna was surveyed from November 2019 to October 2020 in three locations of Kailashahar, Tripura, India. A total of thirty-two species belonging to thirteen families and eighteen genera were identified. Among them nine species are reported for the first time in Tripura, India - Neogeo nocticolor, Tetragnatha mandibulata, Tetragnatha javana, Enoplognatha sp., Oxytate sp., Carrhotus viduus, Thalassius albocinctus, Scytodes fusca and Mimetus sp. The highest numerically abundant spider recorded is Oxyopes scalaris and the least abundant species is Opadometa fastigata in the study area. The present study thoroughly investigated the unexplored spider species distributed over the study area and highlights the richness of spider diversity while calling for greater conservation of forest areas. Further rigorous works are necessary to discover more new spider species from this unexplored state of northeast India.
\end{abstract}

Keywords: spiders, numerical abundance, species diversity, Tripura 


\section{INTRODUCTION}

Spiders (order Araneae) are considered one of the most diverse and numerically abundant groups of arthropods followed by insects. They are widely distributed predaceous organism and explore almost every possible type of habitats (John and Tom, 2018). Their origin dates to the Devonian period (Decae, 1984). The occurrence and distribution of the spiders in a variety of microhabitats functions as a bio-indicator of that area and their presence is influenced greatly by the corresponding habitat and vegetation types (Buddle et al., 2000; De Souza and Martins, 2004; Basumatary and Brahma, 2017). Near about 48,806 species of spiders belonging to 4180 genera and 128 families have been reported globally (World Spider Catalog, 2020) of which more than 1854 species belonging to 474 genera and 61 families are documented from India (Caleb and Sankaran, 2020). Spiders are relatively small in body size, and their body length ranges from $0.37-90 \mathrm{~mm}$. Males are usually smaller than the females and possess shorter life span (Wise, 1993). Spiders play a significant role in the food chain by particularly feeding on insects and other small organisms and are themselves consumed by lizards and birds which helps transmit energy from lower trophic level to higher trophic level (Sharma et al., 2010). Spiders are found to be an effective natural agent to control the population of aphids, leafhoppers, and thrips in the maize field, similarly web-weaving and cursorial spider both can limit the population of Homoptera, Coleoptera, and Diptera in agroecosystems (Vankhede et al., 2016). Being a part of northeast India, the state of Tripura hosts a diverse range of fauna and much of it remains unexplored. Up on review of literature it has been observed that data on spider distribution and occurrence is scanty. The study of spider in Tripura was first initiated by Tikader and Malhotra in 1980 and they reported only a single species. So far, only few attempts have been made to record the spider fauna of the state, for instance, notable contributions have been made by Biswas and Majumder (2000) and Dey et al. (2013) from the state of Tripura, India. However, for sustainable management and conservation of diversity of such organisms, their time-to-time documentation is crucial to enrich global databases and catalogues which may contribute to both spider taxonomy and conservation of diversity (Kashmeera and Sudhikumar, 2019). In this context, the aim of the present study was to identify the spider species distributed in Kailashahar, Unakoti district, Tripura, India and to give an account of their diversity, which can be helpful in the conservation of spiders as well as for preparation of better eco-friendly pest management approach for the farmers of the locality.

\section{MATERIALS AND METHODS}

\section{Study Area}

This study was conducted in the Kailashahar subdivision of Unakoti district, Tripura, India and lies between $24^{\circ} 30.9026^{\prime} \mathrm{N}$ and $92^{\circ} 00.5352^{\prime} \mathrm{E}$. This area is important from the geographical point of view and lies approximately $9 \mathrm{~km}$ away from the Unakoti hill range, the famous pilgrimage spot which serve as abode for thousands of plant and animal species. However, most of the species remain unexplored. The area is marked by high altitude with an approximate elevation of 19 meters and high annual rainfall of $2542.5 \mathrm{~mm}$ (Debbarma et al., 2021). Climate of this area is characterized by moderate warm and humid conditions during summer and moderate cold in winter which is optimum for growth of different types of flora and fauna.

Predominant trees of the study area are Tectona grandis (Verbenaceae), Dipterocarpus turbinatus, Shorea robusta (Dipterocarpaceae), Gmelina arborea (Lamiaceae), Areca catechu, Cocos nucifera (Arecaceae), Mangifera indica (Anacardeaceae), Cassia siamia, Caesalpinia pulcherrima (Caesalpiniaceae), Albizia procera (Osaceae), Musa paradisiacal (Musaceae), Bambusa sp., and Melocanna sp. (Poaceae). Predominant herbs and shrubs include Senna alata, Cassia sophera (Caesalpiniaceae), Cynodon dactylon, Chrysopogon aciculatus (Poaceae), Croton bonplandianum (Euphorbiaceae), Achyranthes aspera (Amaranthaceae), Cyperus sp. (Cyperaceae), Hibiscus rosa-sinensis, Sida cordifolia (Malvaceae), Ocimum sanctum, Leucas lavendulaefolia (Lamiaceae), Crotallaria pallida (Papilionaceae), Solanum torvum (Solanaceae), Mussaenda frondosa (Rubiaceae), Clerodendrum infortunatum (Verbenaceae), and Heliotropium indicum (Boraginaceae). Important crops and vegetables are Oryza sativa (Poaceae), Brassica alba (Brassicaceae), Solanum tuberosum, Solanum melongina, Capsicum annuum, Solanum lycopersicum (Solanaceae), Cucurbita maxima, Cucurbita pepo, Lagenaria siceraria (Cucurbitaceae), Curcuma domestica (Zingiberaceae) and Dolicos lablab (Papilionaceae). Important hydrophytic plants are Eichhornia crassipes, Monochoria vaginalis (Pontederiaceae), Lemna minor (Araceae), Salvinia sp. (Salviniaceae), Marsilea quadrifolia (Marsileaceae), Ipomoea domestica (Convolvulaceae), and Nymphoides hydrophylla (Menyanthaceae). Predominant Pteridophytes include Pteris sp., Adiantum sp. (Pteridaceae), Dryopteris $s p$. (Dryopteridaceae), Lygodium sp. (Lygodiaceae), Selaginella sp. (Selaginellaceae), and Lycopodium $s p$. (Lycopodiaceae). Major Bryophytes of the study area are Riccia sp. (Ricciaceae) Marchantia sp. (Marchantiaceae), Funaria hygrometrica (Funariaceae), and Polytrichum sp. (Polytrichaceae).

The present work studied the diversity and distribution occurrence of spider fauna from November 2019 to April 2020, in three selected 
locations namely Durgapur, Kalipur and Gobindapur located within a radius of approx. $6 \mathrm{sq} . \mathrm{km}$ under Kailashahar sub-division of Unakoti district, Tripura, India.

\section{Data Collection and Species Identification}

Each study site was visited simultaneously by three independent researchers during each sampling day during morning hours (6.00 AM to $8.00 \mathrm{AM}$ ) and again during evening hours (4.00 PM to 6.00 PM) three days a week from November 2019 to October 2020. Three researchers simultaneously laid out stratified transects at three study sites and collected the data. To ascertain diurnal spiders, all probable habitats such as under foliage, crevices, spaces between rocks, etc. were thoroughly searched. Vegetation beating was carried out to determine spiders dwelling in shrubs, secondary vegetation, and trees (Parmar and Patel, 2015). Apart from this, the study also conducted ad libitum methods to determine spider presence in the study sites such as a sweep net were used to collect spider species inhabiting the low vegetation $(10 \mathrm{~cm}-$ $1.5 \mathrm{~m}$ ), litter shifting and by hand to collect visible spiders on trunk or on silk webs (Vedel et al., 2013).

For nocturnal spiders, we used torchlight to observe the eyeshine of spiders. The lycosoid spiders which are mostly nocturnal or crepuscular possess a tapetum lucidum, a part of their eyes which is known to reflect light causing eyeshine (Benson and Suter, 2013). All sighted spiders were photographed and identified with the help of field guides (Sebastian and Peter, 2009; ASBB, 2015; Tikader, 1987; Mondal et al., 2020) and efforts were made to identify up to species level based on their morphological characteristics such as colour pattern, cephalothorax: carapace, sternum, eyes, chelicerae, mouthparts; appendages: legs and palps; abdomen (Jocqué and Dippernaar-Schoeman, 2006; Prajapati et al., 2016). After photographing, individuals were released back in their natural habitats.

\section{RESULTS AND DISCUSSION}

A total of 32 species belonging to 13 families and 18 genera were identified out of 417 individuals encountered during the sampling period (Tab. I). Six species belonged to the family Salticidae, 4 species belonged to the family Tetragnathidae, 9 species belonged to the family Araneidae, 3 species belonged to the family Oxyopidae, 2 species belonged to the family Lycosidae and 1 species each belonged to the families Hersilidae, Sparassidae, Cluboinidae, Pisauridae, Scytodidae, Therididae, Thomisidae and Mimetidae. The highest generic diversity of spider was observed in the family Araneidae (9) followed by Salticidae (6), Tetragnathidae (4) and Oxyopidae (3).

Out of the 32 identified spider species, 9 species were reported for the first time from the state of Tripura, India (Tab. I), which are - Neogeo nocticolor, Tetragnatha mandibulata, Tetragnatha javana, Enoplognatha sp., Oxytate sp., Carrhotus viduus, Thalassius albocinctus, Scytodes fusca and Mimetus sp. Different colours and variation in structures were observed among different spiders which might be linked with the environmental effects (Singh et al., 2020).

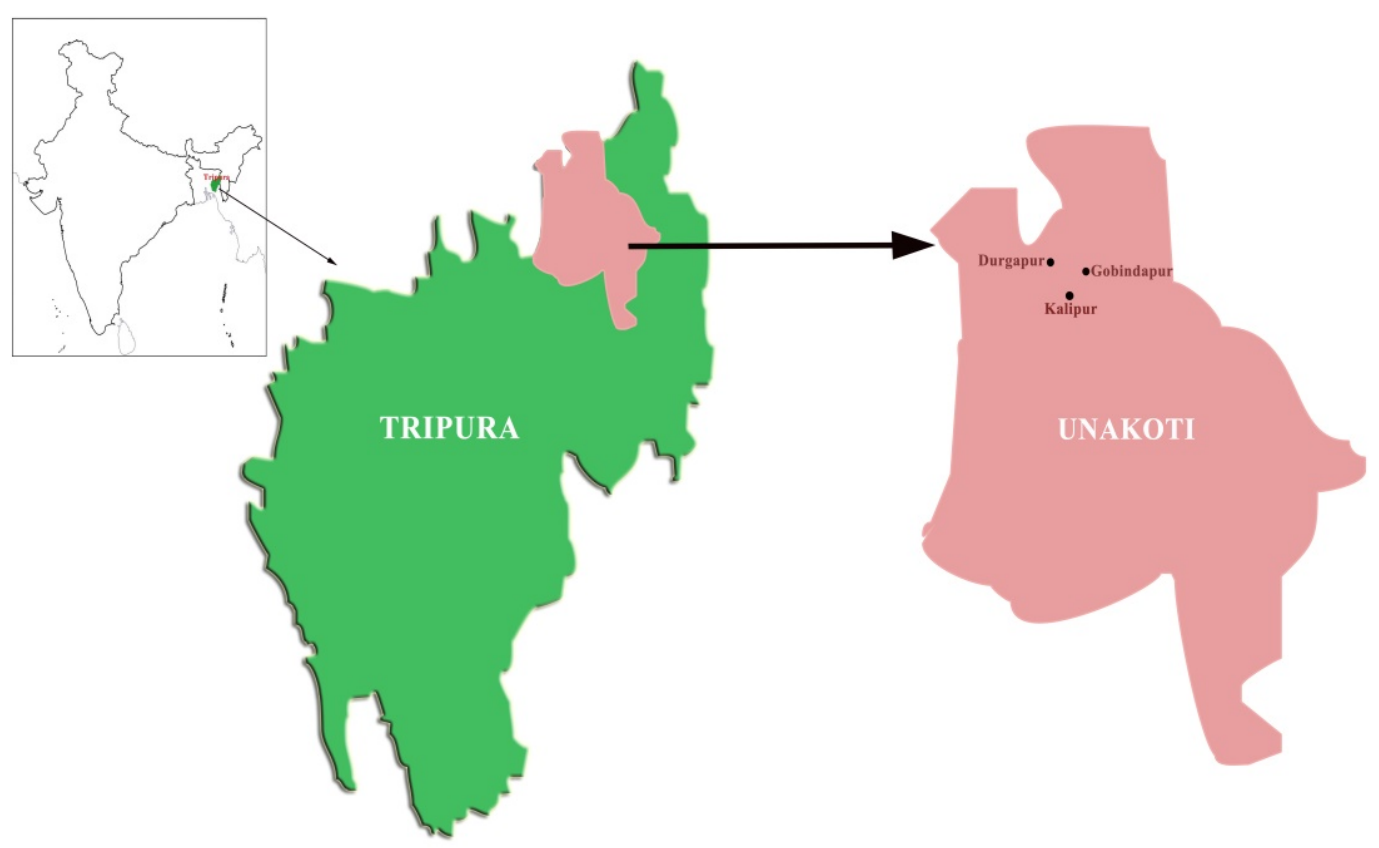

1: Map showing the location of study area. The highlighted map of Unakoti district in Tripura, India depicts the location of three study sites i.e., Durgapur, Kalipur and Gobindapur. 


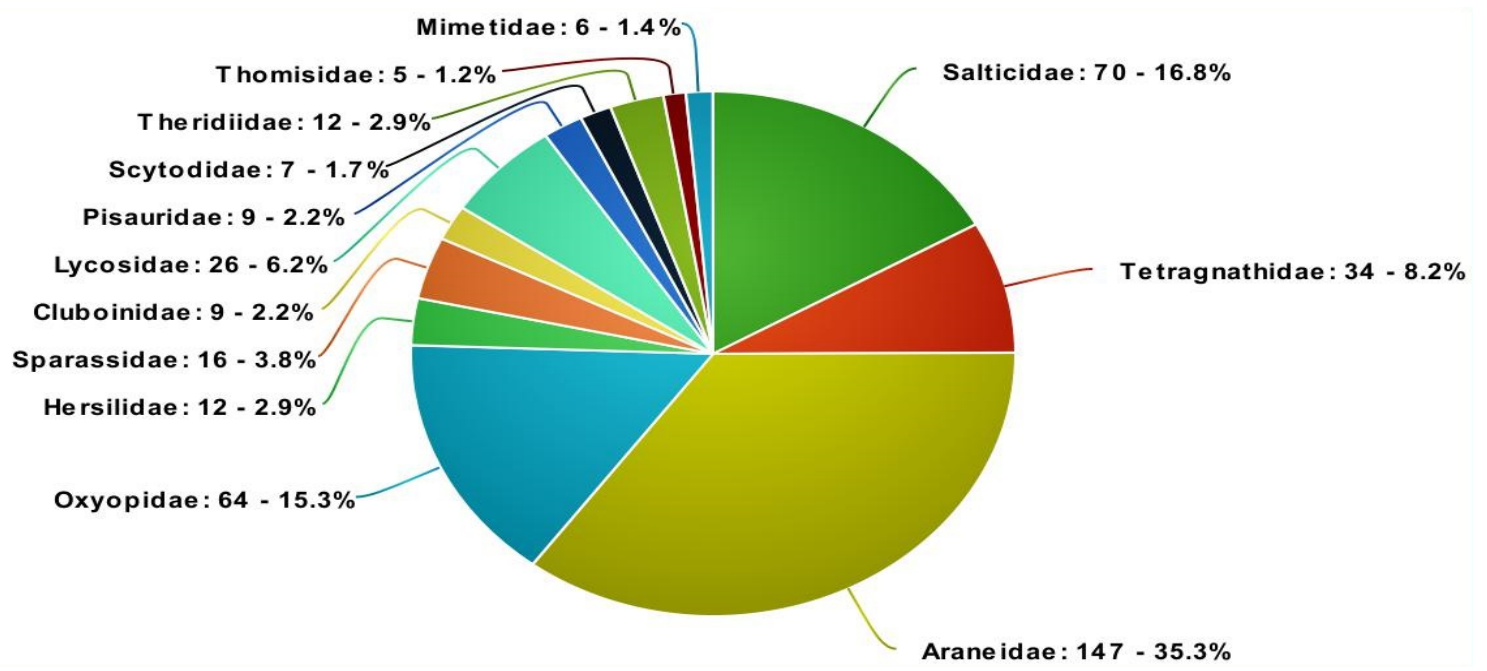

2: Family wise numerical abundance of spider fauna. Total 13 family of spiders are investigated of which highest numerical abundance was showed by Araneidae (147) followed by Salticidae (70), Oxyopidae (64), Tetragnathidae (34), Lycosidae (26), Sparassidae (16), Hersilidae (12), Theridiidae (12), Pisauridae (9), Cludoinidae (9), Scytodidae (7), Mimetidae (6) and Thomisidae (5) int Kailashahar subdivision of Unakoti district, Tripura, India.

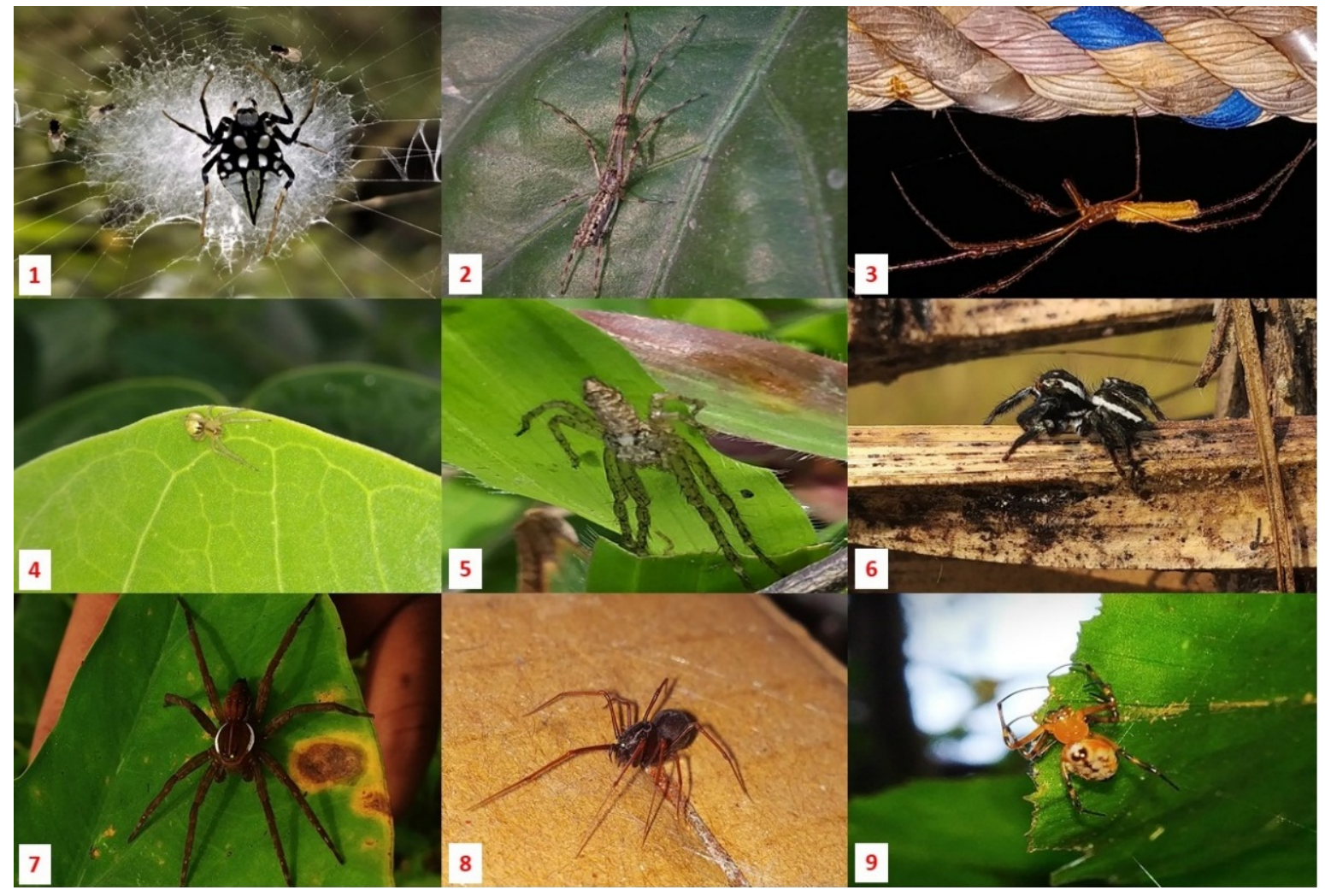

3: Newly identified spider species from Kailashahar. 1. Neogeo nocticolor, 2. Tetragnatha mandibulata, 3. Tetragnatha javana, 4. Enoplognatha sp., 5. Oxytate sp., 6. Carrhotus viduus, 7. Thalassius albocinctus, 8. Scytodes fusca, 9. Mimetus sp.

Among the 32 species, the highest numerical abundance was observed for the species Oxyopes scalaris of Oxyopidae family with 30 individuals (Tab. I) and the lowest was recorded for the species Opadometa fastigata of Tetragnathidae family with only 4 individuals (Tab. I).

The family Araneidae (Fig. 2) was the most numerically dominant taxa of the study site and spiders of this family are generally characterized by entelegyne, three-claw, ecribellate and having eight eyes in two rows (Levi, 2002). A total of nine species were recorded from this family. The species Argiope pulchella was the most dominant spider of this family with 29 individuals and reported earlier from other states of India including Assam (Das et al., 2018), West Bengal (Roy et al., 2016), 
I: List of spider species with number collected from the three study sites i.e. Durgapur, Kalipur and Gobindapur in Kailashahar subdivision of Unakoti district, Tripura

\begin{tabular}{|c|c|c|c|c|}
\hline SL. No. & FAMILY & SPECIES & COUNT(S) & $\begin{array}{l}\text { GUILD STRUCTURES } \\
\text { (Dias et al., 2010; Cardoso et al., 2011) }\end{array}$ \\
\hline 1. & \multirow{6}{*}{ Salticidae } & Siler semiglaucus & 8 & Other hunters \\
\hline 2. & & Menemerus bivittatus & 17 & Other hunters \\
\hline 3. & & Plexippus paykulli & 22 & Other hunters \\
\hline 4. & & Hyllus semicupreus & 9 & Other hunters \\
\hline 5. & & Carrhotus viduus & 7 & Other hunters \\
\hline 6. & & Telamonia dimidata & 7 & Other hunters \\
\hline 7. & \multirow{4}{*}{ Tetragnathidae } & Opadometa fastigata & 4 & Orb Web weavers \\
\hline 8. & & Leucauge decorate & 12 & Orb Web weavers \\
\hline 9. & & Tetragnatha mandibulata & 11 & Orb Web weavers \\
\hline 10. & & Tetragnatha javana & 7 & Orb Web weavers \\
\hline 11. & \multirow{9}{*}{ Araneidae } & Neoscona nautical & 19 & Orb Web weavers \\
\hline 12. & & Gasteracantha kuhli & 14 & Orb Web weavers \\
\hline 13. & & Gasteracantha cancriformis. & 9 & Orb Web weavers \\
\hline 14. & & Cytrophora cicatrosa & 18 & Orb Web weavers \\
\hline 15. & & Argiope pulchella & 29 & Orb Web weavers \\
\hline 16. & & Nephila pilipes & 11 & Orb Web weavers \\
\hline 17. & & Gasteracantha fornicate & 10 & Orb Web weavers \\
\hline 18. & & Argiope anasuja & 25 & Orb Web weavers \\
\hline 19. & & Neogeo nocticolor & 12 & Orb Web weavers \\
\hline 20. & \multirow{3}{*}{ Oxyopidae } & Oxyopes scalaris & 30 & Specialists \\
\hline 21. & & Oxyopes birmanicus & 26 & Specialists \\
\hline 22. & & Hamataliwa incompta & 8 & Specialists \\
\hline 23. & Hersilidae & Hersilia savignyi & 12 & Sensing Web weavers \\
\hline 24 & Sparassidae & Heteropoda venatoria & 16 & Nocturnal aerial ambushers \\
\hline 25. & Cluboinidae & Clubiona drassodes & 9 & Aerial hunters \\
\hline 26. & \multirow{2}{*}{ Lycosidae } & Pardosa pseudoannulata & 11 & Ground runners \\
\hline 27. & & Lycosa sp. & 15 & Ground runners \\
\hline 28. & Pisauridae & Thalassius albocinctus & 9 & Sheet Web weavers \\
\hline 29. & Scytodidae & Scytodes fusca & 7 & Nocturnal aerial runners \\
\hline 30. & Theridiidae & Enoplognatha sp. & 12 & Space Web weavers \\
\hline 31. & Thomisidae & Oxytate sp. & 5 & Ambush Hunters \\
\hline 32. & Mimetidae & Mimetus sp. & 6 & Nocturnal aerial runners \\
\hline
\end{tabular}

Sikkim (Tikader, 1970), Uttar Pradesh (Lawania and Trigunayat, 2013), Tamil Nadu (Caleb, 2020), Gujarat (Prajapati et al., 2018), Goa (Pandit and Pai, 2017), Kerala (Smitha et al., 2020) and Karnataka (Kumari, 2019). The species Argiope anasuja was the second dominant species of this family with 25 individuals, and previously reported from the Indian states of Kerala (Smitha et al., 2020), Uttar Pradesh (Lawania and Trigunayat, 2013), Tamil Nadu (Muthukumaravel et al., 2013), Goa (Pandit and Pai, 2017), Gujarat (Prajapati et al., 2018) and Assam (Singh et al., 2012). The species Neoscona nautical was documented with 19 individuals and it was the third numerically abundant species of this family. It was previously reported from Maharashtra (Archana, 2011), Uttar Pradesh (Radheshyam et al., 2012), Madhya Pradesh (Gajbe, 2003), Gujarat (Parmar et al., 2007), and Karnataka (Deshpande and Paul, 2016) in India. The orb weaver spider Cyrtophora cicatrosa was the fourth 


\section{SPECIES ABUNDANCE}

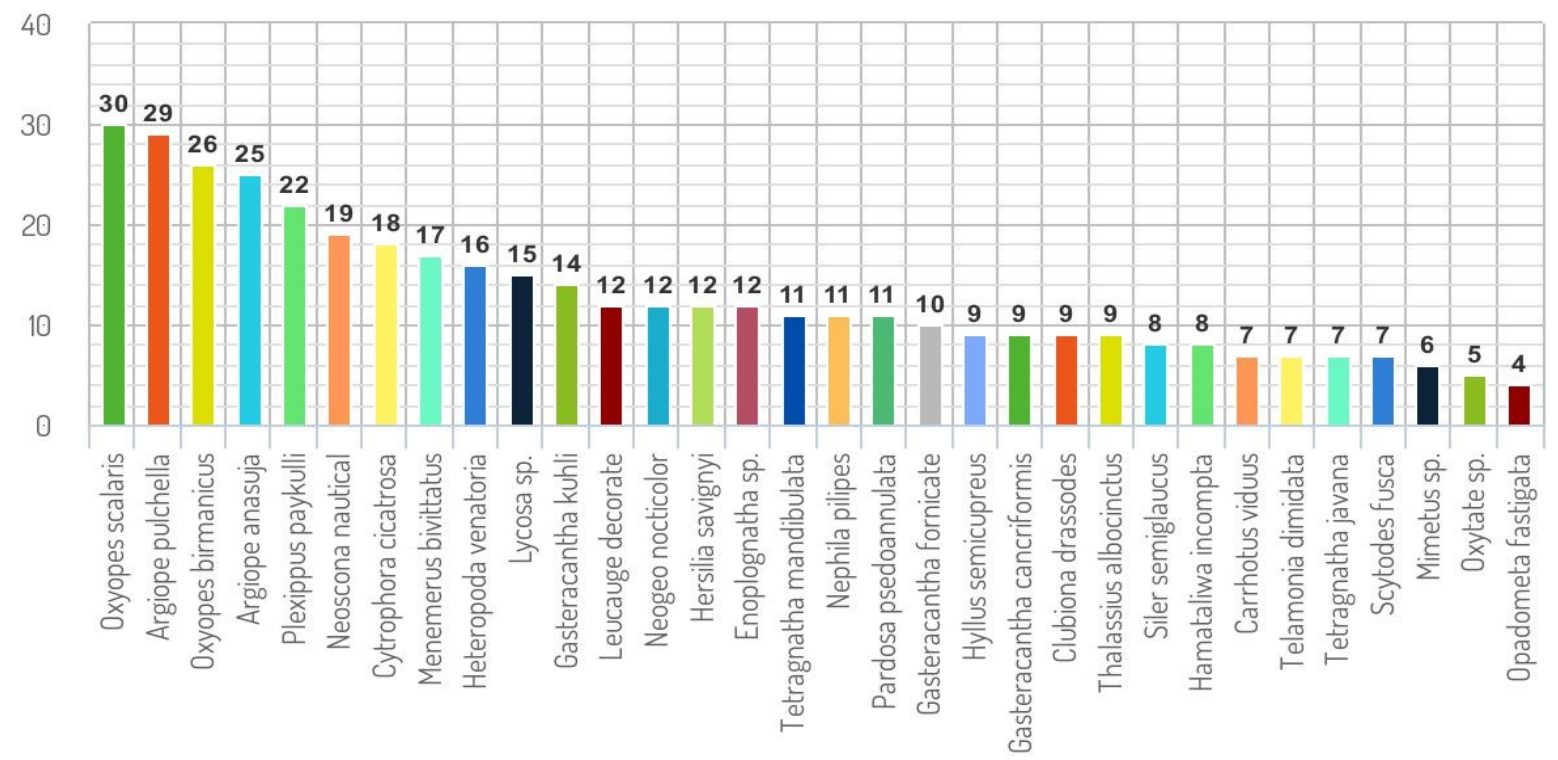

4: Figure demonstrating species wise numerical abundance of spider fauna in Kailashahar subdivision of Unakoti district, Tripura, India. Species count of spider population: Oxyopes scalaris (30), Argiope pulchella (29) Oxyopes birmanicus (26), Argiope anasuja (25), Plexippus paykulli (22), Neoscona nautical (19), Cytrophora cicatrosa (18), Menemerus bivittatus (17), Heteropoda venatoria (16), Lycosa sp. (15), Gastercantha kuhli (14), Leucauge decorate (12), Neogeo nocticolor (12), Hersilia savignyi (12), Enoplognatha sp. (12), Tetragnatha mandibulata (11), Nephila pilipes (11), Pardosa pseudoannulata (11), Gasteracantha fornicate (10), Hyllus semicupreus (9), Gasteracantha cancriformis (9), Clubiona drassodes (9), Thalassius albocinctus (9), Siler semiglaucus (8), Hamataliwa incompta (8), Carrhotus viduus (7), Telamonia dimidata (7), Tetragnatha javana (7), Scytodes fusca (7), Mimetus sp. (6), Oxytate sp. (5), Opadometa fastigata (4).

numerically abundant species with 18 individuals and reported earlier from Andaman \& Nicobar Islands, Gujarat, Kerala, Madhya Pradesh, Maharashtra, Punjab, Tamil Nadu, Uttar Pradesh and West Bengal (Saha et al., 2017) in India. The black and white spider Gasteracantha kuhli holds the fifth position with 14 individuals recorded from the study site. This spider species is generally found inhabiting in shrubby and open forests areas (Pareno et al., 2020). In India, this species was reported from Darjeeling, West Bengal (Roy et al., 2016) and, also Tripura (Dey et al., 2013). The sixth abundant spider species Nephila pilipes of this family was recorded with 11 individuals and reported earlier from the Indian states of Kerala (Adarsh and Nameer, 2015), Assam (Chetia and Kalita et al., 2012), Maharashtra (Amaley, 2012), Uttar Pradesh (Lawania and Trigunayat, 2013), Manipur (Kananbala et al., 2018) and Bihar (Yadav, 2018). The last two species Gasteracantha fornicate and Gasteracantha cancriformis were recorded with 10 and 9 individual spiders, respectively. Gasteracantha cancriformis was reported previously from Maharashtra (Shirbhate and Shirbhate, 2017), Tamil Nadu (Karthikeyani et al., 2017) and Western Ghats (Kapoor, 2008) of India.

The spiders of the family Salticidae are commonly known as jumping spiders and considered as one of the largest families of spiders with around 5000 species distributed worldwide (Wesolowska et al., 2010). In our study six species were reported which belongs to this family (Tab. I). Plexippus paykulli was the most numerically abundant species of spider of this family with 22 individuals and was reported earlier from Tripura (Dey et al., 2013), Karnataka (Kumari, 2019), Uttar Pradesh (Lawania and Trigunayat, 2013), Assam (Chetia and Kalita et al., 2012), Goa (Pandit and Pai, 2017) and Tamil Nadu (Caleb, 2020) in India. Menemerus bivittatus was the second dominant spider species of this family with 17 individuals and was reported previously from West Bengal (Saha et al., 2017), Gujarat (Parmar and Patel, 2015), Manipur (Kananbala et al., 2018) and Assam (Chetia and Kalita et al., 2012) in India. The third most abundant spider species, Hyllussemi cupreus was earlier reported from Maharasthra (Ahmed and Satam, 2015), Kerala (Smitha et al., 2020), Karnataka (Kumari, 2019), Assam (Singh et al., 2012), Rajasthan (Kaur et al., 2014) and Gujarat (Parmar and Patel, 2015) in India. Silersemi glaucus with 8 individuals was first reported from South India in 2015 (Kulkarni and Joseph, 2015) which was later reported again by Roy et al. (2016) from Kerala and West Bengal in India. The least found species of this family Salticidae include Carrhotus viduus and Telamonia dimidiate each with 07 individuals. Carrhotus viduus was reported from Tamil Nadu (Caleb, 2020), Karnataka (Mubeen et al., 2018), Kerala (Adarsh et al., 2015), West Bengal (Roy et al., 2016) and Goa 
(Pandit et al., 2017). Telamonia dimidiate (Simon, 1899) was reported in Maharasthra (Ahmed et al., 2019), Karnataka (Mubeen et al., 2018), Madhya Pradesh (Patil et al., 2013), West Bengal (Roy et al., 2016), Tamil Nadu (Duraimurugan, 2019), Kerala (Sudhikumar et al., 2006), Goa (Pandit et al., 2017) and Assam (Chetia et al., 2012).

The spiders of the Tetragnathidae family build small orb webs and have elongated body, legs and chelicerae. In this study four species of this family was recorded and the species Leucauge decorata was the most dominant spider recorded with 12 individuals from the study site and was reported previously from Uttar Pradesh (Lawania and Trigunayat, 2013), West Bengal (Saha et al., 2017), Kerala (Smitha et al., 2020), Madhya Pradesh (Sharma et al., 2010), Goa (Pandit and Pai, 2017), Tripura (Dey et al., 2013) and Tamil Nadu (Caleb, 2020) in India. Whereas the second most abundant species Tetragnatha mandibulata (Walckenaer, 1841) was reported previously from Kerala (Sebastian et al., 2005), Chennai (Caleb, 2020), Madhya Pradesh (Patil et al., 2013), Uttar Pradesh (Singh et al., 2005), Gujarat (Parmar et al., 2013), Rajasthan (Tikader, 1966) and Orissa (Behera et al., 2010). The third abundant species, Tetragnatha javana was found in Chennai (Caleb, 2020), Kerala (Sebastian, 2005), Assam (Borkakati et al., 2018), Uttar Pradesh (Singh et al., 2014) and West Bengal (Basu et al., 2016). The fourth abundant species, Opadometa fastigata was noted with only 4 individuals from our study site indicating towards its rarity in this topographic region although previously reported from Tamil Nadu (Jeyaparvathi, 2014), Tripura (Dey et al., 2013), Karnataka (Kumari, 2019), Assam (Chetia and Kalita, 2012) and Maharashtra (More and Sawant, 2013).

Spiders belonging to the family Oxyopidae are also known as lynx spiders - named after the catlike hunting behaviour of ambushing or attacking on prey (Brady, 1975). They are commonly known for communal webs which means the web may contain several other individuals, which can include spiders of both sexes as well as both adult and juveniles (Aviles, 1994). From our study area 3 species of this family were recorded and Oxyopes scalaris was the most numerically abundant spider species of this family with 30 individuals and earlier reported from Tripura (Dey et al., 2013) and Assam (Prasad et al., 2019). Oxyopes birmanicus was the second most dominant species with 26 individuals and reported from Meghalaya (Firake and Behere, 2020), Assam (Chetia and Kalita et al., 2012), Tripura (Dey et al., 2013), Goa (Pandit and Pai, 2017), Tamil Nadu (Jeyaparvathi, 2014), Gujarat (Prajapati et al., 2018), Karnataka (Deshpande and Paul, 2016) and Manipur (Singh et al., 2000). The least abundant species of this family was Hamata liwaincompta with only 8 individuals, and was reported previously from Assam (Prasad et al., 2020) and West Bengal (Dhali et al., 2016).
The family Lycosidae, also known as wolf spiders, is of recent evolutionary origin and are typically called as grassland spiders (Jocqué et al., 2005). Two species were recorded from our study, Lycosa sp. with 15 individuals and Pardosa pseudoannulata with 11 individuals. The species Pardosa pseudoannulata was previously reported from Kerala (Adarsh and Nameer, 2015), Tamil Nadu (Caleb, 2020), West Bengal (Dhali et al., 2016), Uttar Pradesh (Lawania and Trigunayat, 2013) and Karnataka (Kumari, 2019). Lycosa sp. were reported in Gujarat (Patel et al., 2001), Madhya Pradesh (Gajbe, 2004), Tamil Nadu (Muthukumaravel et al., 2013), Andaman and Nicobar Islands (Tikader, 1977), and Jammu \& Kashmir (Najar et al., 2016).

The species Hersilia savignyi was the only member of the family Hersilidae noted with 12 individuals from the study site and reported earlier from Goa (Pandit and Pai, 2017), Andhra Pradesh (Pravalikha et al., 2014), Madhya Pradesh (Gajbe, 1992), Gujarat (Prajapati et al., 2018) and Kerala (Smitha et al., 2020). Similarly, Heteropoda venatoria was the only member of the family sparassidae with 16 individuals and reported from Maharashtra (More and Sawant, 2013), West Bengal (Ranade and Prakash, 2016), Assam (Chetia and Kalita et al., 2012) and Kerala (Smitha et al., 2020). The species Clubiona drassodes from Cluboinidae family was reported with 9 individuals from the study site. The species Clubiona drassodes was reported earlier from West Bengal (Dhali et al., 2016), Kerala (Adarsh and Nameer, 2015), Madhya Pradesh (Patil et al., 2013) and Gujarat (Prajapati et al., 2018), too. Enoplognatha $s p$. from Theridiidae family with 12 individuals from the study site were reported earlier from West Bengal (Talukdar et al., 2013) and Kashmir (Khan, 2009). Oxytate sp. belonging to Thomisidae family with only 5 individuals were reported earlier from Assam (Chetia et al., 2012), Manipur (Kananbala et al., 2018), Kerala (Adarsh et al., 2015), Goa (Pandit et al., 2020) and Gujarat (Prajapati et al., 2016). Thalassius albocinctus from the family Pisauridae was reported earlier from Kerala (Jose et al., 2003), West Bengal (Sen et al., 2010), Assam (Chetia et al., 2012) and Maharasthra (More et al., 2013), and a total of 9 individuals were recorded in this study. Scytodes fusca from Scytodidae family with a number of 7 individuals was reported earlier in Kerala (Sudhikumar et al., 2006), Gujarat (Siliwal et al., 2003), Haryana (Malik et al., 2017), Mizoram (Chowdhury et al., 2017) and Maharasthra (More, 2015). Mimetus sp. with only 6 individuals which belong to the family Mimetidae were reported earlier from Kerala (Rajeevan et al., 2019), Gujarat (Yadav, 2019), Tamil Nadu (Karthikeyani et al., 2017), Madhya Pradesh and Chattisgarh (Gajbe, 2003). 


\section{CONCLUSION}

The present study presents a comprehensive overview and an updated checklist of spider species from the state of Tripura. This checklist, a first from Kailashahar sub-division of Unakoti district of Tripura, India documents thirty-two species of spider belonging to eighteen genera. The study envisages to draw attention towards the need for faunal documentation from the state. The present work highlights the richness of spider diversity and documents nine new records from the northeastern state of Tripura in India. It is high time that awareness is created among the young generation to carry out faunal surveys across the state. Based on such surveys, the areas with high richness of species falling outside the protected areas should be declared as Community Conserved Areas. Further thorough and rigorous scientific expeditions and investigations hold promise in paving the way towards the discovery of new insect species from Tripura, India.

\section{Acknowledgements}

The authors are thankful to the Principal of Ambedkar College, Fatikroy, Unakoti, Tripura for providing laboratory facilities. We extend our heartfelt thanks and gratitude to Ashish K. Jangid, WII, Dehradun, Uttarakhand and Rishikesh Tripathi, Christ College, Irinjalakuda, Kerala for their encouragement and immense help with identifications. We also thank Sangeeta Das, Assam Don Bosco University for her help with identifications.

\section{REFERENCES}

ADARSH, C. K. and NAMEER, P. O. 2015. Spiders of Kerala Agricultural University Campus, Thrissur, Kerala, India. Journal of Threatened Taxa, 7(15): 8288-8295.

AHMED, J. and SATAM, Y. 2015. The structure and utilization of silk constructs by Hyllussemicupreus (Simon, 1885) (Araneae: Salticidae). Peckhamia, 125: 1-3.

AHMED, J., KHALAP, R., KUMBHAR, S., HILL, D. E., PEARCE, R. J. and MOHAN, K. 2019. Field notes on the jumping spider Telamonia dimidiata in Maharashtra (Araneae: Salticidae: Plexippina). Peckhamia, 181(1): 1-6.

AMALEY, A. H. 2012. Study of silk glands and silk secreting apparatus in Nephila pilipes. Indian Journal of Arachnology, 1(1): 156-162.

ARCHANA, M. 2011. Spiders (Arachnida: Araneae) from Toranmal Sanctuary, Maharashtra, India. E-International Scientific Research Journal, 3(4): 326-334.

ASBB. 2015. Common Spiders from Select Protected Areas of Upper Assam. Rehabari, Guwahati, Assam, India: Assam State Biodiversity Board, Rehabari, Guwahati, Assam, India.

AVILES, L. 1994. Social behaviour in a web-building lynx spider, Tapinillus sp. (Araneae: Oxyopidae). Biological Journal of the Linnean Society, 52(2): 163-176.

BASU, D. and RAYCHAUDHURI, D. 2016. Rice Land inhabiting Long Jawed Orb Weavers, Tetragnatha Latreille, 1804 (Tetragnathidae: Araneae) of South 24-Parganas, West Bengal, India. World Scientific News, 55: 210-239.

BASUMATARY, P. and BRAHMA, D. 2017. Checklist of spiders from Chakrashila Wildlife Sanctuary, Assam, India. International Journal of Zoology Studies, 2(5): 22-26.

BEHERA, K. S., SAHA, S., BISWAL, G. C., MAJHI, B. K. and RAJAMANI, S. 2010. Population fluctuation of planthoppers and their predators in rain-fed rice. An International Journal on Rice, 47: 238-241.

BENSON, K. and SUTER, R. B. 2013. Reflections on the tapetum lucidum and eyeshine in lycosid spiders. The Journal of Arachnology, 41(1): 43-52.

BISWAS, B. I. J. A. N. and MAJUMDER, S. C. 2000. Arachnida: Araneae. Fauna of Tripura, State Fauna Series. Zoological Survey of India, 7(2): 113-122.

BORKAKATI, R. N., SAIKIA, D. K. and BURAGOHAIN, P. 2018. Natural enemy fauna of paddy and horticultural ecosystems in upper Assam. Indian Journal of Entomology, 80(3): 658-661.

BRADY, A. R. 1975. The lynx spider genus Oxyopes in Mexico and central America (Araneae: Oxyopidae). Psyche, 82(2): 189-243.

BUDDLE C. M., SPENCE J. R. and LANGOR D. W. 2000. Succession of boreal spider assemblages following wildfire and harvesting. Ecography, 23: 424-436.

CALEB, J. T. 2020. Spiders (Arachnida: Araneae) from the vicinity of Araabath Lake, Chennai, India. Journal of Threatened Taxa, 12(1): 15186-15193.

CALEB, J. and SANKARAN, P. 2020. An Online Update to the Spider Checklist of India (Arachnida: Araneae). Araneae of India. Available at: https://indianspiders.in/ [Accessed: 2021, November 15].

CARDOSO, P., PEKÁR, S., JOCQUÉ, R. and CODDINGTON, J. A. 2011. Global Patterns of Guild Composition and Functional Diversity of Spiders. PLOS ONE, 6(6): e21710. 
CHETIA, P. and KALITA, D. K. 2012. Diversity and distribution of spiders from gibbon wildlife sanctuary, Assam, India. Asian Journal of Conservation Biology, 1(1): 5-15.

CHOWDHURY, S. and BOOPATHI, T. 2017. Diversity of predatory spid in rice ecosystem in kolasib. Innovative Farming, 2(1): 12-18.

DAS, S., MAHANTA, N. and KALITA, J. 2018. Argiope pulchella Thorell, 1881 (Araneidae: Araneae): A potential synanthropic species. International Journal of Zoology Studies, 3(2): 265-267.

DEBBARMA, A., KOLOI, S. and SARKAR, D. 2021. Livestock and fodder production scenario of Tripura: An overview. The Pharma Innovation Journal, 10(5): 18-20.

DECAE, A. E. 1984. A theory on the origin of spiders and the primitive function of spider silk. Journal of Arachnology, 12: 21-28.

DESHPANDE, A. and PAUL, R. 2016. Preliminary Study on spiders of Gulbarga, Karnataka State. International Journal of Environment, Agriculture and Biotechnology, 1(4): 238584.

DEY, A., DEBNATH, S., DEBBARMA, B. and CHAUDHURI, P. S. 2013. A preliminary study on spider diversity from a household garden (artificial mixed plantation) in West Tripura, India. Journal of Research in Biology, 3(5): 1009-1017.

DHALI, D. C., ROY, T. K., SAHA, S. and RAYCHAUDHURI, D. 2016. On the new sac spiders (Araneae: Clubionidae) of Dooars, West Bengal, India. World Scientific News, 50: 278-305.

DIAS, S. C., CARVALHO, L. S., BONALDOA, A. B. and BRESCOVIT, A. D. 2010. Refining the establishment of guilds in Neotropical spiders (Arachnida: Araneae). Journal of Natural History, 44; 3-4.

DURAIMURUGAN, M. S. B. 2019. Arthropod Diversity in Horticultural Ecosystems in Keelaiyur Block, Nagapattinam District, Tamil Nadu. Indian Journal of Ecology, 46(4): 889-891.

FIRAKE, D. M. and BEHERE, G. T. 2020. Natural mortality of invasive fall armyworm, Spodopterafrugiperda (JE Smith) (Lepidoptera: Noctuidae) in maize agroecosystems of northeast India. Biological Control, 148: 104303.

GAJBE, U. A. 1992. New Record of Spider Hersilia Savignyi Lucas (Family: Hersiliidae) from Madhya Pradesh India with a Description of Male. Records of the Zoological Survey of India, 90(1-4): 117-119.

GAJBE, P. 2003. Checklist of spiders (Arachnida: Araneae) of Madhya Pradesh and Chhattisgarh. Zoos' Print Journal, 18(10): 1223-1226.

GAJBE, U. A. 2004. Studies on some spiders of the family Lycosidae (Araneae) from Madhya Pradesh, India. Records of the Zoological Survey of India. Occasional Paper No. 221. Kolkata: Zoological Survey of India.

JEYAPARVATHI, S. 2014. Diversity of spider fauna in the cotton field of Thailakulam, Virudhunagar District, Tamil Nadu, India. Journal of Zoology Studies, 1(1): 12-18.

JOCQUÉ, R. and ALDERWEIRELDT, M. 2005. Lycosidae: the grassland spiders. Acta zoologica bulgarica, Suppl. 1: 125-130.

JOCQUÉ, R. and DIPPENAAR-SCHOEMAN, A. S. 2006. Spider families of the world. Tervuren: Royal Museum for Central Africa.

JOHN, R. M. and TOM, H. 2018. A preliminary study on the spider diversity of a rice ecosystem in Kumarakom. Journal of Entomology and Zoology Studies, 6(5): 827-829.

JOSE, K. S., SEBASTIAN, P. A., DAVIS, S. and VARGHESE, A. P. 2003. First record of Thalassius albocinctus (Doleschall) (Araneae: Pisauridae) from India. ENTOMON-TRIVANDRUM, 28: 309-314.

KANANBALA, A., BHUBANESHWARI, M. and SILIWAL, M. 2018. A checklist of spiders (Arachnidae: Araneae) of Manipur, India with some first records and a new species Conothelekhunthokhanbi (Family: Ctenizidae). Journal of Entomology and Zoology Studies, 6(5): 2209-2214.

KAPOOR, V. 2008. Effects of rainforest fragmentation and shade-coffee plantations on spider communities in the Western Ghats, India. Journal of Insect Conservation, 12(1): 53-68.

KARTHIKEYANI, R., CALEB, J. T. D., GAJBE, U. A. and MUTHUCHELIAN, K. 2017. Checklist of spiders (Arachnida: Araneae) of the state of Tamil Nadu, India. Munis Entomology \& Zoology Journal, 12(1): 180-193.

KASHMEERA, N. A. and SUDHIKUMAR, A. V. 2019. A checklist of spider fauna of Rajasthan, India. Journal of Threatened Taxa, 11(1): 13184-13187.

KAUR, M., DAS, S. K., ANOOP, K. R. and SILIWAL, M. 2014. Preliminary checklist of spiders of Keoladeo National Park, Bharatpur, Rajasthan with first record of Ptocasiusstrupifer Simon, 1901 (Araneae: Salticidae) from India. Munis Entomology and Zoology, 9(1): 501-509.

KHAN, A. A. 2009. Biodiversity of spider fauna (Arachnida: Araneae) in the horticultural ecosystem of Kashmir. Indian Journal of Ecology, 36(1): 59-64.

KULKARNI, S. and JOSEPH, S. 2015. First record of genus Siler Simon, 1889 (Araneae: Salticidae) from India. Journal of Threatened Taxa, 7(10): 7701-7703.

KUMARI, S. 2019. A Study on Diversity of Spiders at Malavagoppa Village, in Shimoga District, Karnataka. International Journal of Environment, Agriculture and Biotechnology, 4(2): 544-555. 
LAWANIA, K. K. and TRIGUNAYAT, M. M. 2013. Baseline studies on the spider fauna (Araneae) of Braj Region (Brajbhoomi) India. International journal of Biotechnology and Bioengineering Research, 4: 16-19.

LEVI, H. W. 2002. Keys to the genera of araneid orbweavers (araneae, araneidae) of the americas. The Journal of Arachnology, 30(3): 527-562.

MALIK, V. and GOYAL, V. 2017. Biodiversity of spiders in different habitats of Western Haryana, India. Journal of Entomology and Zoology Studies, 5(4): 822-825.

MONDAL, A., CHANDA, D., VARTAK, A. and KULKARNI, S. 2020. A Field Guide to the Spider Genera of India. Siddharth Kulkami.

MORE, S. and SAWANT, V. 2013. Spider fauna of Radhanagari wildlife sanctuary, Chandoli National Park and Koyna wildlife sanctuary. Indian Journal of Arachnology, 2(1): 81-92.

MORE, S. B. 2015. Spider diversity of Rundiv, Sidheshwar and Ramnadi area of Chandoli National Park. International Journal of Research in Biosciences, Agriculture and Technology, 3(2): 90-101.

MUBEEN, M. and BASAVARAJAPPA, S. 2018. Density, abundance, and percent occurrence of spider species (Arachnida: Araneae) in and around Mysore city, Karnataka, India - A case study. IOSR Journal of Pharmacy and Biological Sciences, 13(3): 31-40.

MUTHUKUMARAVEL, K., AMSATH, A. and RAJA, R. B. 2013. A preliminary investigation of spider fauna in associated mangroves of Muthupet at Adirampattinam Coast, Tamil Nadu, India. International Journal of Pure and Applied Zoology, 1: 304-309.

NAJAR, I. A. and BASHIR, A. 2016. Insect diversity of Doodhpathri (Budgam), Jammu and Kashmir, India. International Journal of Fauna and Biological Studies, 3(6): 28-32.

PANDIT, R. and PAI, I. K. 2017. Spiders of Taleigao Plateau, Goa, India. Journal of Environmental Science and Public Health, 1(4): 240-252.

PANDIT, R. and DHARWADKAR, M. 2020. Preliminary checklist of spider fauna (Araneae: Arachnida) of Chandranath Hill, Goa, India. Journal of Threatened Taxa, 12(11): 16597-16606.

PARENO, T. and DEMAYO, C. G. 2020. Variability in the cephalothorax shape within and between populations of the spiny orb weaver spider Gasteracantha kuhli. Arthropods, 9(3): 74-84.

PARMAR, B. M., NAGRAL, N., JOSHI, V., BARIA, K. and PAWAR, C. 2007. Some Spiders from in and around the Caves of Taranga Hills, Mahesana, Gujarat, India. Journal of Pharmaceutical and Biomedical Analysis, 43(4): 1470-1475.

PARMAR, B. M. and ACHARYA, A. V. R. L. N. 2013. The spider fauna of Pariej Wetland, Gujarat, India. Int. J. Sci. Res, 4(10): 1028-1033.

PARMAR, B. M. and PATEL, K. B. 2015. Study of spider diversity from Vadnagar taluka, Gujarat. Life Science Leaflets, 64: 94-101.

PATEL, B. H. and VYAS, R. 2001. Spiders of Hingolgadh Nature Education Sanctuary, Gujarat, India. Zoos' Print Journal, 16(9): 589-590.

PATIL, S. R., SAMBATH, S. and BHANDARI, R. 2013. Preliminary investigation on spiders (Arachnida: Araneae) in Rani Veerangana Durgawati wildlife sanctuary, Damoh, Madhya Pradesh, India. Indian Forester, 139(10): 943-946.

PRAJAPATI, D. A., PATEL, K. R., MUNJPARA, S. B., CHETTIAR, S. S. and JHALA, D. D. 2016. Spiders (Arachnida: Araneae) of Gujarat University Campus, Ahmedabad, India with additional description of Eilica tikaderi (Platnick, 1976). Journal of Threatened Taxa, 8(11): 9327-9333.

PRAJAPATI, J. N., PATEL, S. R., SURANI, P. M. and RADADIA, G. G. 2018. Agrobiont spiders (Araneae) from Five Ecosystems of Navsari Agricultural University, Navsari, Gujarat, India. International Journal of Chemical Studies, 6(3): 2547-2550.

PRASAD, A. K., ROY, S., SEN, S., NEAVE, S., NAGPAL, A. and PANDIT, V. 2020. Impact of different pest management practices on natural enemy population in tea plantations of Assam special emphasis on spider fauna. International Journal of Tropical Insect Science, 40(3): 629-635.

PRAVALIKHA, G. B., SRINIVASULU, C. and SRINIVASULU, B. 2014. New species of genus Hersilia Audouin, 1826 (Araneae: Hersiliidae) from India. Journal of Threatened Taxa, 6(3): 5553-5557.

RADHESHYAM, M., CHAUBEY, S. N. and GHUFRAN, A. 2012. Study on the morphology, feeding capacity and prey preference of orb-weaving spider Neosconanautica (L. Koch, 1875). Journal of Experimental Zoology India, 15(2): 467-472.

RAJEEVAN, S., KUNNATH, S. M., VARGHESE, T. and KANDAMBETH, P. P. 2019. Spider diversity (arachnida: araneae) in different ecosystems of the western ghats, wayanad region, India. S. Asian J. Life Sci, 7(2): 29-39.

RANADE, S. P. and PRAKASH, V. 2016. Parasitization of a huntsman spider (Arachnida: Araneae: Sparassidae: Heteropoda venatoria) by a mermithid nematode (Nematoda: Mermithidae). Journal of Threatened Taxa, 8(13): 9595-9596.

ROY, T. K., SAHA, S. and RAYCHAUDHURI, D. 2016. A treatise on the jumping spiders (Araneae: Salticidae) of tea ecosystem of Dooars, West Bengal, India. World Scientific News, 53(1): 1-66. 
SAHA, S., DAS, I. and RAYCHAUDHURI, D. 2017. Spider Faunal Diversity of Barasat and Basirhat, 24 Parganas, West Bengal, India. World News of Natural Sciences, 15: 49-85.

SEBASTIAN, P. A., MATHEW, M. J., BEEVI, S. P., JOSEPH, J. and BIJU, C. R. 2005. The spider fauna of the irrigated rice ecosystem in central Kerala, India across different elevational ranges. The Journal of Arachnology, 33(2): 247-255.

SEBASTIAN, P. A. and PETER, K. V. 2009. Spiders of India. Hyderabad: Universities Press.

SEN, S., SAHA, S. and RAYCHAUDHURI, D. 2010. New and hitherto unknown nursery web spider species (Araneae: Pisauridae) from the reserve forests of Dooars, West Bengal, India. Mun. Ent. Zool., 5(1): 225-231.

SHARMA, S., VYAS, A. and SHARMA, R. 2010. Diversity and abundance of spider fauna of Narmada River at Rajghat (Barwani) (Madhya Pradesh) India. Researcher, 2(11): 113-117.

SHIRBHATE, M. V. and SHIRBHATE, A. M. 2017. Diversity and distribution of spider fauna (familyAraneidae) in and around Katepurna Sanctuary, Akola, India. Environment Conservation Journal, 18(3): 45-52.

SILIWAL, M., SURESH, B. and PILO, B. 2003. Spiders of Purna Wildlife Sanctuary, Dangs. Gujarat. Zoos' Print Journal, 18(11): 1259-1263.

SINGH, B. B. and SINGH, R. 2014. Incidence and Biodiversity of Riceland Spiders (Arthropoda: Arachnida) in Northeastern Uttar Pradesh, India. Indo-American Journal of Life Sciences and Biotechnology, 2(1): 64-89.

SINGH, D., NEGI, A. K. and PUROHIT, J. C. 2020. Effect of Environmental Factors on Phenology of Wild Species of Anacardiaceae in Garhwal Himalaya. Indian Journal of Ecology, 47(2): 456-461.

SINGH, R. B., GUPTA, P. K., PRASAD, S. S. and SINGH, R. A. 2005. Prevalence and composition of different spiders in upland rice ecosystem. Journal of Plant Protection and Environment, 2(1): 41-45.

SINGH, R. T., DEVI, M. B., DEVI, A. K. and CHINGANGBAM, D. S. 2000. Comparative cytology of four families of spiders from two districts of Manipur, India. Journal of Entomology and Zoology Studies, 46-54.

SINGH, S., BORKOTOKI, A. and SARMAH, C. K. 2012. Species distribution of Spiders in Barpeta district of Assam: A diversity measure. E-International Scientific Research Journal, 4(1): 47-57.

SMITHA, M. S. and SUDHIKUMAR, A. V. 2020. A diversity of spiders (Arachnida: Araneae) from a cashew ecosystem in Kerala, India. Journal of Threatened Taxa, 12(13): 16879-16884.

SOUZA A. L. T. D. and MARTINS R. P. 2004. Distribution of plant-dwelling spiders: inflorescences versus vegetative branches. Austral Ecol., 29: 342-349.

SUDHIKUMAR, A. V., MATHEW, M. J., SUNISH, E. and SEBASTIAN, P. A. 2006. Synanthropic spiders of Kerala, India. Science and Technology for Sustainable Development, 3(2): 265-267.

TALUKDAR, S. and SANYAL, A. K. 2013. First record of the genus Nesticodes Simon, 1894 from India with taxonomic studies on a red cob-web-spider Nesticodes rufipes (Lucas, 1846) (Araneae: Theridiidae) from West Bengal, India. Records of the Zoological Survey of India, 113(3): 41-47.

TIKADER, B. K. 1966. On a collection of spiders (Araneae) from the desert area of Rajasthan (India). Rec. Indian Mus, 59(4): 435-443.

TIKADER, B. K. 1970. Spider fauna of Sikkim. Records of the Zoological Survey of India, 64(1-4): 1-84.

TIKADER, B. K. 1977. Studies on spider fauna of Andaman and Nicobar Islands, Indian Ocean. Records of the Zoological Survey of India, 72: 153-212.

TIKADER, B. K. and MALHOTRA, M. S. 1980. Fauna of India. Araneae. Vol. I. Delhi: Government of India.

TIKADER, B. K. 1987. Handbook Indian Spiders: A Manual for the study of the Spiders and their relatives-The Scorpions, Pseudoscorpions, Whip scorpions, Harvestmen and all members of the Class Arachnida found in India with analytical keys for their classification and biology. Calcutta: Zoological Survey of India.

VANKHEDE, G., HADOLE, P. and CHAKRAVARTHY, A. K. 2016. Spiders: Diversity, Distribution, and Conservation. In: Arthropod Diversity and Conservation in the Tropics and Sub-tropics. Singapore, pp. 139-164.

VEDEL, V., RHEIMS, C., MURIENNE, J. and BRESCOVIT, A. D. 2013. Biodiversity baseline of the French Guiana spider fauna. Springer Plus, 2: 361.

WESOŁOWSKA, W. and VAN HARTEN, A. 2010. Order Araneae, family Salticidae. Arthropod Fauna of the UAE, 3: 27-69.

WISE, D. H. 1993. Spiders in ecological webs. Cambridge, Cambridge University Press.

WORLD SPIDER CATALOGUE. 2020. World Spider Catalog. Version 21.5. Natural History Museum Bern. [Online]. Available at: http://wsc.nmbe.ch [Accessed: 2020, October 10].

YADAV, A. 2019. Diversity and ecology of spiders in champaner pavagadh archaeological park a world heritage site in Gujarat. Doctoral dissertation. Maharaja Sayajirao University of Baroda India.

YADAV, R. S. 2018. First report of Nephila clavata L. Koch, 1878 (Araneae: Araneidae) from Bihar and Uttar-Pradesh, India. Journal of Entomology and Zoology Studies, 6(1): 754-756. 
Contact information

Shubhadeep Roychoudhury: shubhadeep1@gmail.com (corresponding author)

(c) (i) $(-)$ This work is licensed under a Creative Commons Attribution-NonCommercial-NoDerivatives 4.0 c. 